\title{
Herbal Medicines and Reactivation of Chronic Hepatitis B Virus Infection
}

\author{
Cyriac Abby Philips ${ }^{1,}{ }^{*}$, Philip Augustine ${ }^{2}$ and Guruprasad Padsalgi ${ }^{2}$ \\ ${ }^{1}$ The Liver Unit, Ernakulam Medical Center, Cochin, India \\ ${ }^{2}$ Department of Gastroenterology, Ernakulam Medical Center, Cochin, India \\ "Corresponding author: Cochin Gastroenterology Group, Philip Augustine Associates, Kochi, Kerala, India. Tel: +91-9207745776, Email: abbyphilips@gmail.com
}

Received 2018 June 19; Revised 2018 August 20; Accepted 2018 September 15.

Keywords: Hepatitis B, Reactivation, Flare, Ayurveda, CAM, Alternative Medicine, Phytochemical, ACLF

\section{Background}

Reactivation of chronic hepatitis $\mathrm{B}$ virus infection (rHBV) is defined as the sudden reappearance or increase in HBV DNA in a patient with resolved or known/unknown inactive HBV infection sometimes associated with clinical presence of hepatitis and leading to acute on chronic liver failure (ACLF). Reactivation can occur in hepatitis B surface antigen (HBsAg) positive, hepatitis B envelope antigen (HBeAg) positive, or antibody to hepatitis B envelope antigen (anti HBe) positive individuals. It can also occur in patients who have cleared the virus (HBsAg negative) but with positive antibodies to hepatitis B core antibodies (anti $\mathrm{HBc}+\mathrm{ve}$ ). In the latter cases, precore mutant, core promoter mutant, and HBV DNA polymerase mutants are implicated along with potential triggers. The other wellknown causes leading to sudden rHBV include immunosuppressive treatments including cancer chemotherapy and corticosteroid treatment, post solid organ and bone marrow transplantation, coinfection with human immunodeficiency virus, other acute viral hepatitis, hepatitis $C$ virus on treatment, significant alcoholism, uncontrolled diabetes mellitus, sudden withdrawal of HBV antivirals, any major surgical stress and post-ablation/resection for hepatocellular carcinoma, and pregnancy (1).

\section{Methods}

From August 2017 to May 2018, 984 new patient registrations in emergency and outpatient departments of the liver unit were analysed for hepatitis B surface antigen (HBsAg) positivity (Supplementary Appendix 1). Hepatitis B surface antigen (HBsAg) was found positive in 48 (4.87\%) patients, of which 11 were diagnosed with compensated or decompensated cirrhosis, 22 patients were healthy subjects who were incidentally detected surface antigen positive, and 15 patients had rHBV. We excluded liver disease patients who were on follow up and those who were already diagnosed with and on treatment or follow up for HBV infection. We defined rHBV as alanine aminotransferase $($ ALT) $>10 x$ upper limit of normal and HBV DNA > $10 \log (2)$, and rHBV leading to ACLF was defined as per the European Association for the Study of the Liver-Chronic Liver Failure (EASL-CLIF) Consortium recommendation (3). In the rHBV patients, we performed detailed analysis of history, comorbid conditions, clinical investigations, and drugs used to identify the causes for reactivation. Three patients ( $n=15,20 \%$ ) presented as ACLF. All the patients diagnosed with $\mathrm{HBV}$ infection were initiated on antiviral therapy or followed up as per the current recommended treatment and monitoring guidelines proposed by the EASL (4). Informed consent was obtained from all the participants included in the study. The study was performed after the required institutional review board and ethical committee approval and was performed according to the principles defined in the 1975 Declaration of Helsinki, International Conference on Harmonization, Good Clinical Practice.

\section{Results}

The baseline characteristics and causes of reactivation are presented in Table 1 and 2, of which one patient in the ACLF and two patients in the non-ACLF group had significant Ayurveda and herbal medicine (AHM) intake in the absence of other known causative factors for reactivation.

Two patients $(n=15,13.3 \%)$, both with ACLF and one with AHM use, died during a median follow up of 248 (range 12 to 369) days. Typical causations for reactivation were 


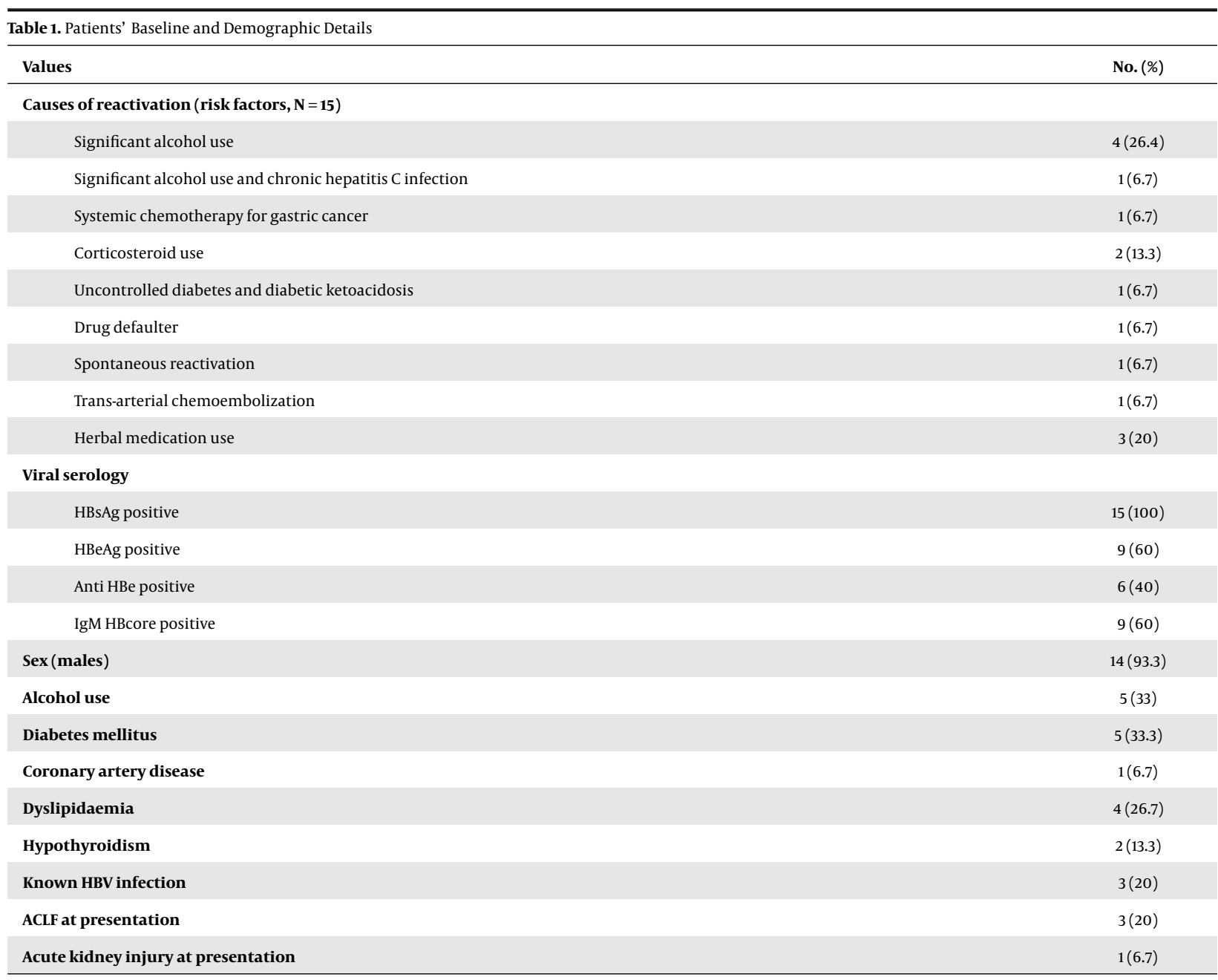

identified in almost all ( $\mathrm{n}=11$, significant alcohol use, antiviral defaulter, coinfection, uncontrolled diabetes mellitus with ketoacidosis, chemotherapy, surgical stress, radiological intervention and corticosteroid use), except for one patient (anti-HBcore +ve and anti $\mathrm{HBe}+\mathrm{ve}$ ) who had controlled systemic hypertension and dyslipidemia and absence of described causative factors associated with rHBV. Multiple common herbal components with immunomodulating properties were noted in the AHM ingested by three patients with rHBV without associated classical factors for reactivation (Table 3).

\section{Discussion}

Kamitsukasa et al. described two septuagenarians, one with coronary artery disease without HBV mutations and another with recurrent esophageal cancer and diabetes with a precore G1896A variant with high quasi-species diversity, both developing rHBV in the absence of cancer chemotherapy or immunosuppression (5). They suggested that aging, surgical stress, and complication of chronic diseases such as cancer associated with compromised immunity may trigger spontaneous HBV reactivation. Talbodec et al. suggested that precore mutations were not always found in patients with chronic hepatitis B who develop HBV DNA-positive/HBeAg-negative reactivation (6). It is interesting to note that in our study, out of three patients who developed rHBV, one with well controlled diabetes mellitus while the others without comorbidities or classical risk factors for rHBV, had intake of AHM prior to clinical symptom development.

A literature search on the common herbal components revealed the presence of plant alkaloids and steroids with strong immunomodulating properties as phytochemical constituents in the AHM. For example, andrographolide, a bioactive agent from Andrographis panniculata has been shown to increase steroid sensitivity in a mouse model of bronchial asthma (7). Tinospora cordifolia has been 


\begin{tabular}{|c|c|c|c|c|c|}
\hline Parameters & Minimum & Maximum & Mean & Median & SD \\
\hline Age, $y$ & 29 & 69 & 53.4 & 56.000 & 11.8 \\
\hline Hemoglobin, $\mathrm{g} / \mathrm{L}$ & 9.8 & 15.4 & 11.6 & 11.400 & 1.5 \\
\hline Total leucocyte count, per mm ${ }^{3}$ & 3900 & 18400 & 9200 & 8600.000 & 4492.8 \\
\hline Platelet count, $\times 10^{9} / \mathrm{mm}^{3}$ & 0.76 & 3.2 & 1.8 & 1.900 & 0.6 \\
\hline Total bilirubin, mg/dL & 4.2 & 30.1 & 10.7 & 11.9 & - \\
\hline Direct bilirubin, mg/dL & 2.1 & 18.6 & 7.4 & 6.800 & 4.6 \\
\hline Alanine transaminase, IU/L & 440 & 3971 & 1503.2 & 1168.000 & 1048.4 \\
\hline Aspartate transaminase, IU/L & 233 & 3399 & 751 & 669 & - \\
\hline Alkaline phosphatase, IU/L & 1.4 & 224 & 137.4 & 128 & 63.7 \\
\hline Gamma glutamyl transpeptidase, IU/L & 97 & 227 & 140.5 & 119 & 47.5 \\
\hline Blood urea nitrogen, mg/dL & 6 & 72 & 15.9 & 14 & - \\
\hline Creatinine, $\mathbf{m g} / \mathbf{d L}$ & 0.6 & 2.8 & 1.1 & 1.1 & - \\
\hline International normalized ratio & 1 & 3.4 & 1.5 & 1.4 & - \\
\hline Serum sodium, mmol/L & 128 & 139 & 136.1 & 137 & 2.8 \\
\hline Serum potassium, $\mathbf{m m o l} / \mathrm{L}$ & 2.9 & 4.9 & 3.9 & 4.1 & 0.5 \\
\hline Hepatitis B surface antigen, IU/ml & 332 & 10428 & 5077.6 & 4582 & - \\
\hline Hepatitis B DNA, IU/mL & 11200 & 15468000 & 3680575.3 & 238000 & - \\
\hline Follow up, d & 12 & 369 & 228.4 & 248 & 116.3 \\
\hline
\end{tabular}

shown to contain glycosides and plant steroids such as beta-sitosterol, ecdynosterone, and gilonisterol with anabolic activity (8). The presence of alkaloids, natural phenolic agents, and glycosides in Terminalia chebula has been shown to modulate cell-mediated and humoral immunity in animal models (9). Our patients in whom possible AHM was implicated as a cause of rHBV, unlike those described by Kamitsuka et al., were not elderly and did not suffer from uncontrolled metabolic syndrome or cancer.

Genetic polymorphisms and decreased expression of specific human leucocyte antigen (HLA) expression in the presence of immunomodulatory agents have been implicated in recent rHBV studies (10). Even though we did not assess genetic polymorphisms, considering HLA expression variability and HBV mutations in our patients with rHBV, we believe that the presence of such factors may have been contributory and that the use of AHM with rich immunomodulating components would have incited the severe flares seen in our patients, akin to those seen with biological agents such as infliximab, rituximab, and interferons. In the current study, we were more interested in shedding light on novel triggers for severe flares of chronic HBV infection. Although reactivations can occur spontaneously, they are often triggered by immunosuppression such as due to chemotherapy, rituximab treatment, or following solid organ transplantation. In litera- ture, there is large data on reactivations of HBV triggered in the presence of biologicals or due to steroid use and chemotherapeutic agents. We believe that almost all of these studies were on HBsAg negative/surface antigen mutants (11). In our series, all the patients were HBsAg-positive with severe reactivation following known triggers that led to immunomodulation (such as steroids, alcohol, and uncontrolled diabetes) and novel triggers such as AHM. Hence, in patients with known or unknown chronic hepatitis B infection, apart from assessing typical risk factors and causations associated with reactivation, careful appraisal of drug use, especially Ayurvedic and herbal medications, where such practices are widely followed, need to be considered as potential triggers for severe flares. Larger studies in such populations entrenched in traditional medicine practice could help identify herbal components associated with reactivation of HBV so that vigilance and patient education can be imparted to prevent life threatening liver-related events.

\section{Supplementary Material}

Supplementary material(s) is available here [To read supplementary materials, please refer to the journal website and open PDF/HTML]. 


\begin{tabular}{|c|c|c|c|c|c|}
\hline Patient & $\begin{array}{l}\text { Reason for Intake of } \\
\text { Herbal Medicine }\end{array}$ & $\begin{array}{l}\text { Duration } \\
\text { of } \\
\text { Intake }\end{array}$ & Outcome & Name of Herbal Medicine & Components of Herbal Medicine \\
\hline \multirow{2}{*}{$\begin{array}{l}\text { A } 65 \text {-year-old male, no } \\
\text { features of acute on } \\
\text { chronic liver failure, } \\
\text { controlled diabetes } \\
\text { mellitus }(>8 \text { y) }\end{array}$} & \multirow{2}{*}{$\begin{array}{l}\text { Upper respiratory tract } \\
\text { infection and loss of } \\
\text { appetite }\end{array}$} & \multirow{2}{*}{$3 w$} & \multirow{2}{*}{ Alive } & Histantin (polyherbal formulation) & $\begin{array}{l}\text { Andrographis panniculata }{ }^{\mathrm{a}}, \text { Bambusa } \\
\text { arundinacea, Tinospora cordifolia }^{\mathrm{a}} \text {, } \\
\text { Cuminum cyminum }^{\mathrm{a}}, \text {, }^{2} \text { corus calamus }\end{array}$ \\
\hline & & & & $\begin{array}{l}\text { Powdered dried flowers and leaves } \\
\text { of Bitter Oleander }\end{array}$ & Holarrherna pubescens \\
\hline \multirow{3}{*}{$\begin{array}{l}\text { A 66-year-old male, no } \\
\text { features of acute on } \\
\text { chronic liver failure, no } \\
\text { comorbidities }\end{array}$} & \multirow{3}{*}{$\begin{array}{l}\text { Non-specific } \\
\text { polyarthralgia, change in } \\
\text { taste and loss of appetite }\end{array}$} & \multirow{3}{*}{$3-4 w$} & \multirow{3}{*}{ Alive } & $\begin{array}{l}\text { Powdered dried stem and leaves of } \\
\text { White Ginger Lily }\end{array}$ & Hedychium malayanum \\
\hline & & & & $\begin{array}{l}\text { Powdered dried whole seeds of } \\
\text { Common Cumin }\end{array}$ & 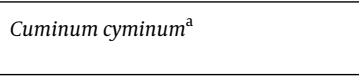 \\
\hline & & & & $\begin{array}{l}\text { Ajmodadi churna (polyherbal } \\
\text { formulation) }\end{array}$ & $\begin{array}{l}\text { Trachyspermum ammi, Embelia ribes }{ }^{\mathrm{a}} \text {, } \\
\text { Cedrus deodara }{ }^{\mathrm{a}}, \text { Plumbago zeylanica, } \\
\text { Terminalia chebula }^{\mathrm{a}} \text {, Argyreia nervosa, } \\
\text { Zingiber officinale }{ }^{\mathrm{a}} \text {, Anathallis } \\
\text { graveolens }\end{array}$ \\
\hline \multirow{2}{*}{$\begin{array}{l}\text { A 65-year-old female } \\
\text { with acute-on-chronic } \\
\text { liver failure, no } \\
\text { comorbidities }\end{array}$} & \multirow{2}{*}{$\begin{array}{l}\text { Fever, cough, wheezing } \\
\text { and loss of appetite }\end{array}$} & \multirow{2}{*}{$2-3 w$} & \multirow{2}{*}{ Died } & $\begin{array}{l}\text { Dhanwantharam gulika; } \\
\text { (polyherbal formulation) }\end{array}$ & 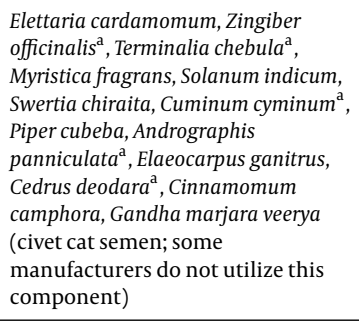 \\
\hline & & & & $\begin{array}{l}\text { Abhyarishta; (polyherbal } \\
\text { formulation) }\end{array}$ & $\begin{array}{l}\text { Terminalia chebula }{ }^{\mathrm{a}} \text {, Vitis vinifera, } \\
\text { Madhuca indica, Embelia ribes }{ }^{\mathrm{a}} \text {, } \\
\text { Tribulus terrestris, Operculina } \\
\text { turpetum, Coriandrum sativum, } \\
\text { Woodfordia fruticose, Citrullus } \\
\text { colocynthis, Piper retrofractum, } \\
\text { Zingiber officinale }^{\mathrm{a}}, \text { Baliospermum } \\
\text { momtanum, Salmalia malabarica }\end{array}$ \\
\hline
\end{tabular}

\footnotetext{
${ }^{\text {a }}$ Represent components common to all three patients, in the ingested herbal medications.
}

\section{References}

1. Hoofnagle JH. Reactivation of hepatitis B. Hepatology. 2009;49(5 Suppl):S156-65. doi: 10.1002/hep.22945. [PubMed: 19399803].

2. Jindal A, Kumar M, Sarin SK. Management of acute hepatitis B and reactivation of hepatitis B. Liver Int. 2013;33 Suppl 1:164-75. doi: 10.1111/liv.12081. [PubMed: 23286861].

3. Arroyo V, Jalan R. Acute-on-chronic liver failure: Definition, diagnosis, and clinical characteristics. Semin Liver Dis. 2016;36(2):109-16. doi: 10.1055/s-0036-1583202. [PubMed: 27172351].

4. European Association for the Study of the Liver. EASL 2017 clinical practice guidelines on the management of hepatitis B virus infection. J Hepatol. 2017;67(2):370-98. doi: 10.1016/j.jhep.2017.03.021. [PubMed: 28427875].

5. Kamitsukasa H, Iri M, Tanaka A, Nagashima S, Takahashi M, Nishizawa $\mathrm{T}$, et al. Spontaneous reactivation of hepatitis B virus (HBV) infection in patients with resolved or occult HBV infection. J Med Virol. 2015;87(4):589-600. doi: 10.1002/jmv.24115. [PubMed: 25612181].

6. Talbodec N, Loriot MA, Gigou M, Guigonis V, Boyer N, Bezeaud A, et al. Hepatitis B virus precore mutations and $\mathrm{HBeAg}$ negative reactivation of chronic hepatitis B after interferon therapy. Liver. 1995;15(2):93-8. [PubMed: 7540713].
7. Liao W, Tan WS, Wong WS. Andrographolide restores steroid sensitivity to block lipopolysaccharide/IFN-gamma-induced IL-27 and airway hyperresponsiveness in mice. J Immunol. 2016;196(11):4706-12. doi: 10.4049/jimmunol.1502114. [PubMed: 27183596].

8. Saha S, Ghosh S. Tinospora cordifolia: One plant, many roles. Anc Sci Life. 2012;31(4):151-9. doi: 10.4103/0257-7941.107344. [PubMed: 23661861]. [PubMed Central: PMC3644751].

9. Bag A, Bhattacharyya SK, Chattopadhyay RR. The development of terminalia chebula retz. (Combretaceae) in clinical research. Asian Pac J Trop Biomed. 2013;3(3):244-52. doi: 10.1016/S2221-1691(13)60059-3. [PubMed: 23620847]. [PubMed Central: PMC3631759].

10. Matsuda H, Hiramatsu K, Akazawa Y, Nosaka T, Saito Y, Ozaki Y, et al. Genetic polymorphism and decreased expression of HLA class II DP genes are associated with HBV reactivation in patients treated with immunomodulatory agents. J Med Virol. 2018;90(4):712-20. doi: 10.1002/jmv.25011. [PubMed: 29283185].

11. Caligiuri P, Cerruti R, Icardi G, Bruzzone B. Overview of hepatitis $B$ virus mutations and their implications in the management of infection. World J Gastroenterol. 2016;22(1):145-54. doi: 10.3748/wjg.v22.i1.145. [PubMed: 26755866]. [PubMed Central: PMC4698481]. 